\title{
Pakistan National \\ Organic Cotton \\ Policy GAP Analysis
}

March 2021

\section{Authors}

Babar Latif Baloch

Ashfaque Ahmed Nahiyoon

Abdul Rehman

Mohsin Zulqarnain Hussain

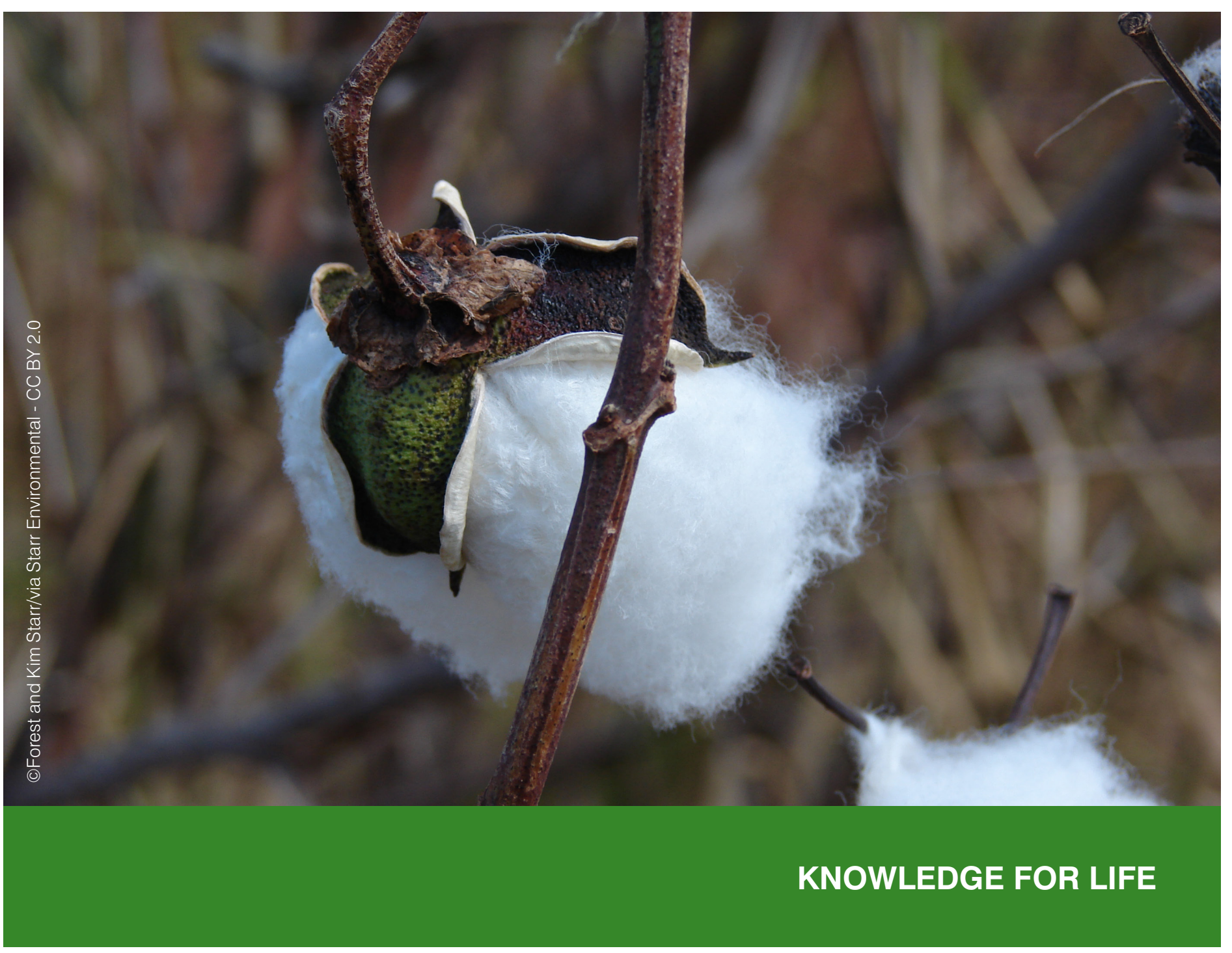




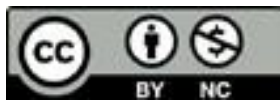

The copyright holder of this work is $\mathrm{CAB}$ International (trading as $\mathrm{CABI}$ ). It is made available under a Creative Commons Attribution-Non-commercial Licence (CC BY-NC). For further details please refer to http://creativecommons.org/license.

We would like to thank those stakeholders who responded to the GAP analysis questionnaire and shared their knowledge to help produce this report.

The preparation of this paper was made possible through funding provided by the Laudes Foundation for the 'Cotton Advocacy for Policy and Seed (CAPAS)' project.

$\mathrm{CABI}$ is an international intergovernmental organisation, and we gratefully acknowledge the core financial support from our member countries (and lead agencies) including the United Kingdom (Foreign, Commonwealth \& Development Office), China (Chinese Ministry of Agriculture and Rural Affairs), Australia (Australian Centre for International Agricultural Research), Canada (Agriculture and Agri-Food Canada), the Netherlands (DirectorateGeneral for International Cooperation) and Switzerland (Swiss Agency for Development and Cooperation). See http://www.cabi.org/about-cabi/who-we-work-with/key-donors/ for full details.

This CABI Working Paper was internally peer-reviewed. It may be referred to as:

Baloch, B.L., Nahiyoon, A.A., Rehman, A. and Hussain, M.Z. (2021) Pakistan National

Organic Cotton Policy GAP Analysis. CABI Working Paper 19, 26 pp.

https://dx.doi.org/10.1079/CABICOMM-62-8145

Babar Latif Baloch, CABI, Opposite 1-A, Data Gunj Baksh Road, Satellite Town, PO Box 8, Rawalpindi, Pakistan

Email: b.baloch@cabi.org; ORCID: 0000-0001-9597-1464

Ashfaque Ahmed Nahiyoon, Provincial Coordinator TIBCRAW, Green Climate Fund (GCF) Project-Sindh, Food and Agriculture Organization of the United Nations, House 76, Defence Officers Housing Scheme, Hyderabad, Sindh, Pakistan

Email: ashfaquenahiyoon@gmail.com

Abdul Rehman, CABI, Opposite 1-A, Data Gunj Baksh Road, Satellite Town, PO Box 8, Rawalpindi, Pakistan

Email: a.rehman@cabi.org; ORCID:0000-0002-2958-9870

Mohsin Zulqarnain Hussain, CABI, Opposite 1-A, Data Gunj Baksh Road, Satellite Town, PO Box 8, Rawalpindi, Pakistan

Email: M.Abbasi@cabi.org; ORCID: 0000-0003-3196-4112

Front cover image: Cotton boll, by Forest and Kim Starr (Starr Environment), made available under $\underline{\mathrm{CC}-\mathrm{BY}}$ license. 


\section{Table of contents}

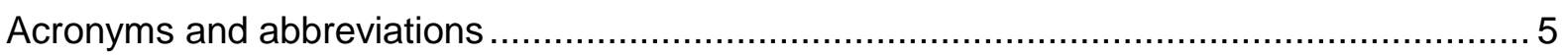

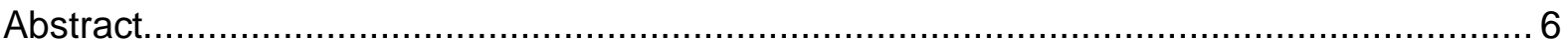

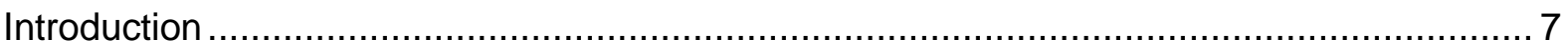

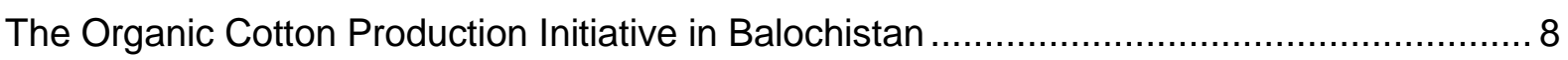

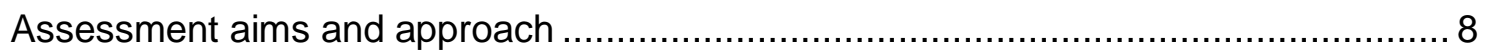

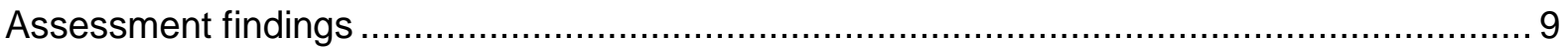



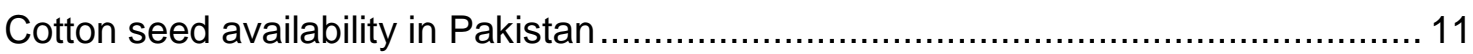

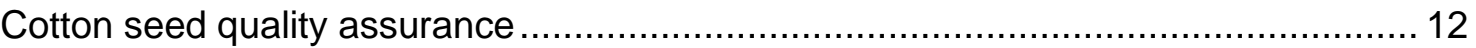

Availability of non-GMO cotton varieties in Pakistan ............................................ 13

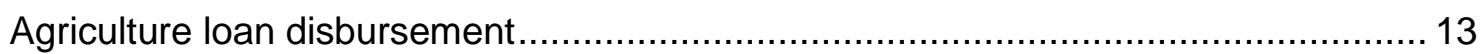

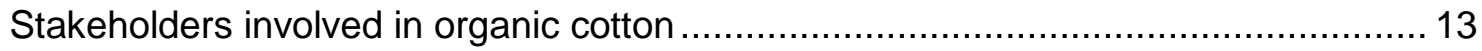

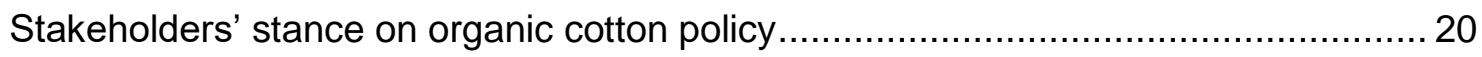

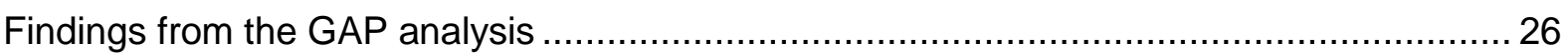

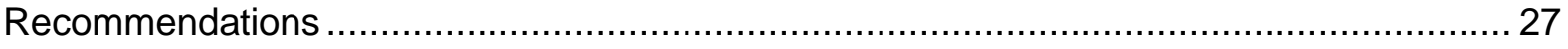

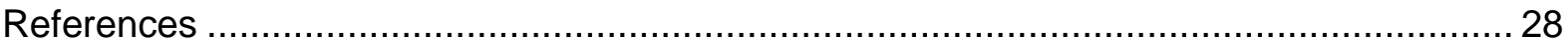




\section{Acronyms and abbreviations}

\begin{tabular}{|c|c|}
\hline AARI & Ayyub Agriculture Research Institute \\
\hline API & Agriculture Policy Institute \\
\hline APTMA & All Pakistan Textile Mills Association \\
\hline BASPS & Balochistan Agriculture Sector Policy and Strategy \\
\hline $\mathrm{Bt}$ & Bacillus thuringiensis \\
\hline CAPAS & Cotton Advocacy for Policy and Seed \\
\hline CCRI & Central Cotton Research Institute \\
\hline DAE & Department of Agriculture Extension \\
\hline FAO & Food and Agriculture Organization of the United Nations \\
\hline FSC\&RD & Federal Seed Certification and Registration Department \\
\hline GAP & Good agricultural practice \\
\hline GMO & Genetically modified organism \\
\hline ICT & Information and communication technology \\
\hline IPM & Integrated pest management \\
\hline ISO & International Organisation for Standardisation \\
\hline KCA & Karachi Cotton Association \\
\hline KSC & Kauns Seed Corporation \\
\hline MNFS\&R & Ministry of National Food Security \& Research \\
\hline NIAB & Nuclear Institute of Agriculture and Biology \\
\hline NIBGE & National Institute for Biotechnology and Genetic Engineering \\
\hline NIGAB & National Institute for Genomics and Advanced Biotechnology \\
\hline PARC & Pakistan Agriculture Research Council \\
\hline PCCA & Pakistan Cotton Cess Act \\
\hline PCCC & Pakistan Central Cotton Committee \\
\hline PCCO & Punjab Cotton Control Ordinance \\
\hline PCGA & Pakistan Cotton Ginners Association \\
\hline PCSI & Pakistan Cotton Standards Institute \\
\hline PSC & Punjab Seed Corporation \\
\hline PTP & Pakistan Textile Policy \\
\hline R\&D & Research and development \\
\hline SAB & Sindh Abadgar Board \\
\hline SBP & State Bank of Pakistan \\
\hline TSC & Tassco Seed Corporation \\
\hline WWF & World Wildlife Fund For Nature \\
\hline
\end{tabular}




\section{Abstract}

Pakistan is the fourth largest cotton producer in the world and cotton is a mainstay of Pakistan's economy. CABI and cotton stakeholders, under the Cotton Advocacy for Policy and Seed project, conducted an analysis of gaps in existing policies, documents, and regulatory frameworks, and suggested new policies needed to scale-up organic cotton production. The analysis focuses on Balochistan, the first province to harvest organic cotton in Pakistan.

The analysis found that farming communities are interested in producing profitable organic cotton, but need more government support in: (i) provision of an organic agriculture loan facility; (ii) increased availability of bio-inputs; and (iii) provision of an organic cotton premium. The following recommendations are made:

- A seed multiplication system should be created.

- Seed quality assurance is required to ensure that non-GMO seed is available.

- A national certification and laboratory testing system is required.

- The private sector should be engaged to help all elements of an organic cotton supply chain to emerge.

- The State Bank of Pakistan needs to create a credit facility for organic cotton farmers.

- A capacity building programme on integrated pest management and good agricultural practice for organic farmers is required.

Pakistan can benefit from growing international demand for organic cotton if concrete interventions are put in place. The government is keen to put a long-term strategy in place to increase organic cotton production, develop new high-yielding varieties, establish an organic textile supply chain, and facilitate farmers in getting good quality inputs, credit, and prices for their crops. 


\section{Introduction}

Cotton is the major cash crop in Pakistan, contributing $9.5 \%$ of gross domestic product and is a source of livelihoods for 15 million cotton workers in the country. It directly and indirectly brings in US $\$ 3.5$ billion as foreign currency each year. The income from cotton is also important to cotton-producing households, accounting for nearly $40 \%$ of total household income among landowners, and nearly $45 \%$ of total household income among sharecroppers (Cororaton and Orden, 2008).

Pakistan is one of the leading producers of cotton, but two particularly important factors that have affected cotton production and its quality are the indiscriminate use of pesticides and chemical fertilisers. Of the total pesticides sprayed in Pakistan each year, $80 \%$ are used on cotton crops. Cotton growers tend to spray their crops too often and apply too much due to the belief that high doses increase crop production. These poor practices, however, not only damage the crops but also put the health of farming communities at risk.

Prevailing climatic conditions, water shortages, and increasing health expenditures (on skin and cytogenic diseases) are all signs that there needs to be a shift in the current cotton production system. Increasing organic cotton demands from the USA, Europe, the UK, and other high-end apparel markets have also sent strong signals to developing countries, such as Pakistan, that if they are able to make shifts at policy and field level they will be able to reap significant financial rewards.

The current government of Pakistan is keen to form a long-term cotton strategy that focuses on sustainability as well as increasing the area under cotton production, developing new highyield varieties, establishing supply chains, and helping farmers access good quality inputs, credit, and prices for their crops.

Punjab produces $79 \%$ and Sindh produces $20 \%$ of the total cotton each year, with Balochistan and Khyber Pakhtunkhwa collectively producing just $1 \%$ of the cotton. Balochistan is the largest province of Pakistan (forming $46 \%$ of the country's area) and is considered a land of opportunity, especially for developing organic agriculture. This is because much of its land remains unutilised due to a lack of well-connected physical, technological, and human infrastructure. Although Balochistan is blessed with huge but untapped agricultural resources, it depends on Punjab and Sindh for agricultural inputs, including seed. Balochistan's provincial government is keen to take proactive steps to make the province a hub for organic agriculture, especially cotton. The province's Department of Agriculture Extension (DAE) has recently created its first agriculture policy, and a strategy for agriculture promotion, assisted by the Food and Agriculture Organization of the United Nations (FAO) (Government of Balochistan, 2015), with financial assistance from the United States Agency for International Development and Australia's Department of Foreign Affairs and Trade. 


\section{The Organic Cotton Production Initiative in Balochistan}

Organic cotton is grown using methods and inputs that have a minimum impact on the environment. The Laudes Foundation (formerly the C\&A Foundation) launched an organic cotton production project in Balochistan (2016-2019) with the World Wildlife Fund for Nature (WWF) Pakistan as the implementing partner, along with DAE. By 2019, 2,800 farmers from the Barkhan and Lasbela districts of Balochistan (Figure 1) had been trained on the importance of organic cotton, associated incentives, capacity building on agronomic practices and bio-input preparation methods, while DAE field staff had been engaged in sensitising the farming community to cultivate and guide organic cotton cultivation and the development of a viable supply chain.

The third year of the organic cotton production project (20182019) saw 181 farmers from both project districts achieving organic certification. The project



Figure 1: Map of Balochistan. Source:

http://www.freeworldmaps.net/asia/pakistan/balochistan/balochistandistricts-map.jpg (accessed 12 Feb 2021) was extended for another year, which led to the certification in 2019-2020 of an area of 2,913 ha, farmed by 883 farmers, with a production of 5,455 t of organic cotton seed. The project linked supply chain actors with project farmers, and ultimately developed an organic cotton supply chain, which resulted in the procurement of organic cotton produce by ginners, and the production of around 9,800 organic cotton bales.

\section{Assessment aims and approach}

To further support policy at a national and provincial level, CABI (with funding from the Laudes Foundation under CABl's Cotton Advocacy for Policy and Seed (CAPAS) project) conducted an organic cotton policy good agricultural practice (GAP) analysis. The scope of the assignment was to:

- Define the role of regulations, policies, procedures, and guidelines in the policy framework for organic agriculture in Balochistan and Pakistan, with a special emphasis on cotton. 
- Gather and provide policy briefs, procedures, and guidelines to promote organic agriculture, especially cotton, in the province, and to examine those policies that are detrimental to organic agriculture in general.

- Identify policy advocacy bodies that can be approached for guidance and collaboration, including government departments that should be targeted for advocacy efforts.

- Identify, discuss, suggest, and document implications and gaps in policy or regulation that should be included in the framework.

- Engage in policy and advocacy for seeking subsidies or organic inputs (non-GMO seed, 'desi' cotton seed, biopesticides, etc.).

- Scan the evidence regarding non-GMO seed availability.

- Identify demand and supply gaps for non-GMO seed and other inputs.

- Identify the potential for non-GMO seed multiplication through organic farmers.

- Identify seed certification gaps and challenges.

- Determine institutional capacity regarding non-GMO variety development and seed multiplication.

- Understand the supply and value chain of organic cotton.

- Trace international and national key players in the GMO seed sector, fertilisers, and potential resistance at each level.

- Determine the status of credit disbursement and training regarding organic farmers in Balochistan.

- Identify the relevant members for provincial working groups on organic cotton.

- Identify organic cotton growth hotspots in Sindh, Balochistan, and Punjab, focusing on virgin lands.

This assessment was carried out through a desk review of relevant laws, policies and literature and stakeholder interviews. A total of 21 interviews were carried out with participants from both national and provincial levels who have a role in cotton production.

\section{Assessment findings}

\section{Review of existing policy documents (1923-2020)}

The Pakistan Cotton Cess Act (PCCA) $1923^{1}$ refers to cotton duties imposed on cotton ginning and other supply chain activities and cotton rate fixation through The Gazette of Pakistan, but contains nothing on the importance of organic cotton or the production system.

\footnotetext{
116 March 1923, modified 1 June 1951 after the creation of Pakistan.
} 
The Cotton Transport Act 1923, amended in 1960, provides guidelines for declaring a cotton protected area (Government of Pakistan, 1960). It also outlines restrictions to be imposed on the transport of cotton in certain circumstances, to maintain the quality and reputation of the cotton grown in any area, and to prohibit the importation of cotton by any route.

The Punjab Cotton Control Ordinance (PCCO) 1966 (Government of West Pakistan, 1966) covers almost all aspects relating to cotton processing, such as ginning and pressing. The PCCO prevents the construction of any new factory, or any extension to an existing factory that is likely to increase capacity for ginning, pressing cotton or crushing cotton seed, unless a licence has been granted. This act also sets a standard for the weight of a cotton bale (standard net weight of $170 \mathrm{~kg}$, with a variation of plus or minus $5 \%$ at $8.5 \%$ moisture content and with an average weight of $17,000 \mathrm{~kg}$ for a cotton lot of 100 bales, with variation of up to plus or minus $3 \%$ ). It also prohibits contamination with any matter other than cotton, making it a punishable offence.

The PCCO 1966 allows stakeholders to impose restrictions on growing cotton varieties to ensure that particular areas cultivate a specific trait-containing variety; no person is allowed to sell seed of any variety or hybrid except the one that is designated in the area. This clause is conducive to promoting organic cotton in certain specific areas first, then expanding its cultivation to other areas if sustainable and economically viable results are achieved.

The Pakistan Cotton Standards Institute (PCSI) was established in 2002 in Karachi, along with two regional offices at Multan (Punjab) and Sukkur (Sindh), under the Cotton Standardization Ordinance, 2002 (Government of Pakistan, 2002). This ordinance gives authority to the PCSI to establish more regional offices according to the need of the country. As Balochistan is growing its cotton production area, especially organic cotton, there is a need to establish a regional PCSI office in Balochistan.

The Pakistan Textile Policy (PTP) 2014-2019 (Government of Pakistan, 2015) focuses on establishing model cotton trading houses, and plant breeders' rights, to facilitate research, and the availability of certified cotton seed, but it is silent on cotton production, its management, and standardisation. The policy suggests establishing cotton grading and classification for proper cotton premium payments, but no incentive is suggested for organic cotton growers and input suppliers.

International markets are always viewed as prime target markets but unfortunately Pakistan's cotton value has decreased by about $10 \%$ during the last few years due to poor grading and standardisation, high levels of cotton trashes, and the mixing of various cotton varieties at every step of the cotton value chain (PTP 2014-2019). While existing textile tariffs are designed to protect local cotton industries, they are a major cause of inefficiency along the cotton supply chain and makes Pakistan textile products undesirable and uncompetitive in international markets (PTP 2014-2019).

The focus of the Balochistan Agriculture Sector Policy and Strategy (BASPS) 2015 (Government of Balochistan, 2015) will be achieved through the proactive role of the provincial government in creating institutional, legal, and incentive systems to support agriculture, particularly in terms of job creation and value addition of agriculture products, including cotton. 


\section{Seed company regulations}

A 'seed business' is defined in the 2015 amendment to the Pakistan Seed Act, 1976 (Government of Pakistan, 1976) as any commercial operation of seed involving the production, processing, conditioning, packaging, distribution, import, and export of seed. Section 22A of the Business Rules of the Federal Seed Certification and Registration Department (FSC\&RD) allows for the registering or enlisting of imported plant varieties or hybrids for general cultivation on the basis of the results of multi-location trials for at least two crop seasons. A different ordinance was approved by the federal government for the registration of varieties and the protection of the rights and legal status of seed breeders/businesses, as well as the promotion of further research and development (R\&D) in the seed domain in the country to meet future challenges.

\section{Biosafety rules and guidelines for seed}

The National Biosafety Guidelines (Government of Pakistan, 2005) were formulated in order to protect seed business in Pakistan. Framed under the Pakistan Environment Protection Act 1997, these rules regulate various aspects of the import, export, production, trials and sale of seeds of all major and minor crops in Pakistan. The National Biosafety Committee (chaired by the Federal Secretary, Ministry of Environment) is among the three committees (Technical Advisory Committee, chaired by the Director General, Pakistan Environmental Protection Agency and the Institutional Biosafety Committee, chaired by the head of the institution concerned) under these rules is empowered:

- to establish standards and procedures for risk assessment and labelling of living modified organisms, substances or cells and products;

- to ban or restrict import, export, sale, purchase or trading of any living modified organism causing or likely to cause risk to public health, safety or the environment; and

- to cooperate with other relevant federal and provincial authorities overseeing the import and release of living organisms and formulate guidelines for the identification, inspection and regulation of transgenic species, exotic organisms, and others.

Rule 19 of said rules says that production in which living modified engineered organisms, substances or cells or products thereof or microorganisms are generated or used shall not be commenced except with the consent of the National Biosafety Committee. This shall also apply to production taking place in connection with development, testing, and experiments.

\section{Cotton seed availability in Pakistan}

Although Pakistan is among the top five cotton-producing countries in the world, its cotton crop is under immense pressure due to: (i) farmers' changing preferences towards other crops like sugarcane; (ii) climatic changes; (iii) acute water shortages; and above all (iv) the unavailability of pure non-GMO cotton seed in the country.

shows the availability of cotton seed in Pakistan. For organic cotton production, the quantity of non-GMO seed remained meagre until the 2019-2020 cotton season when $4.2 \mathrm{t}$ of pure non-GMO seed were provided to CAPAS project farmers for multiplication to help the seed 
scarcity situation for the 2020 season, starting in April. Farmers who cultivate both Bt (Bacillus thuringiensis) and non-Bt cotton rarely bother about cross-pollination and as a result the chances of cotton seed contamination are very high. This challenge can be addressed by farmer education and training for proper seed multiplication and separation of $\mathrm{Bt}$ and non-Bt cotton seed varieties.

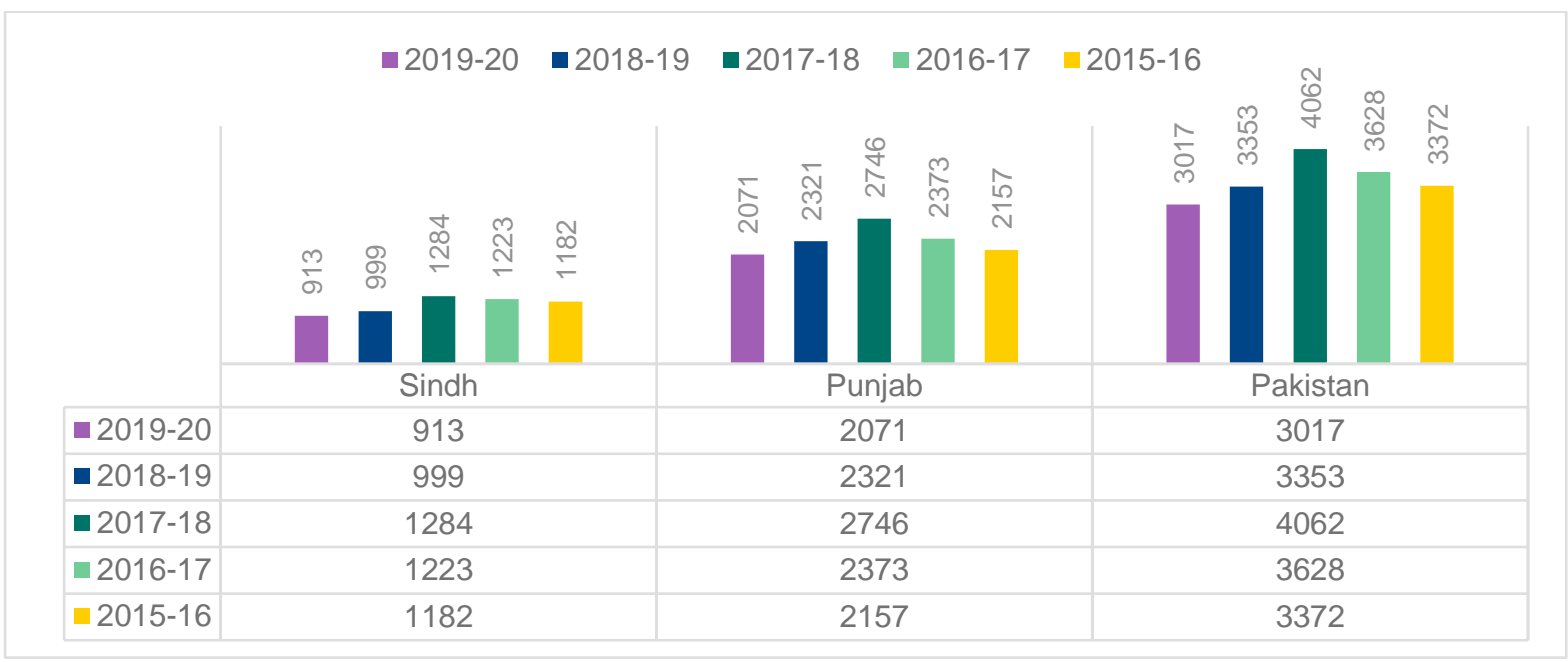

Figure 2: Total cotton seed availability in Pakistan (000 t)

Source: Pakistan Central Cotton Committee (PCCC) (2020)

\section{Cotton seed quality assurance}

This analysis also reviewed cotton seed quality assurance. A good number of non-GMO varieties are available from seed research institutes for use in organic cotton production, but due to contamination issues concerning Bt traces in the field, the quality of the seed is often compromised. Unfortunately, most non-GMO cotton seed samples taken from research institutes were actually found to be GMO positive. To ensure that farmers have access to high quality non-GMO seed, changes need to be implemented along the entire cotton seed supply chain. A number of actions are needed:

- Immediate: Stakeholders such as the Ministry of National Food Security \& Research (MNFS\&R), FSC\&RD, and organic cotton farming communities should be engaged to further specify their needs and explore feasible steps forward, especially at the policy level under the Seed Act 1976 (Government of Pakistan, 1976).

- Short term: Seed multiplication under CABl's CAPAS project should be extended to more farmers, engaged seed companies, and public-sector seed research institutes to meet the growing demand for organic cotton production in Pakistan.

- Long term: Non-GMO cotton seed multiplication, involving seed research institutes, should be developed. 


\section{Availability of non-GMO cotton varieties in Pakistan}

Pakistan has established various cotton variety development institutes across the country to meet the changing demands of the textile sector at the national and international level. These research institutes have access to cotton foundation germplasm seed which needs to be multiplied for organic cotton needs, especially for virgin land available in Balochistan, Sindh and Punjab, and its purity maintained.

\section{Agriculture loan disbursement}

The State Bank of Pakistan (SBP), being the central bank of Pakistan, has regulations that are conducive for all commercial banks operating in the country regarding how they offer agriculture loans to farming communities. Agriculture loans are disbursed through more than 20 commercial banks. There are agriculture-specialised banks, including Zarai Tarqiati Bank Limited. A baseline study of CABl's CAPAS project shows that more than $90 \%$ of farmers are illiterate and so struggle to deal with bank formalities to access agricultural loans.

\section{Stakeholders involved in organic cotton}

\section{List of stakeholders}

The ministries, departments, institutes and bodies listed as stakeholders in Table 1 were identified and connected through CAPAS project activities. They can be approached for guidance and collaboration for advocacy efforts, and for further work on and approval of organic cotton policy. 
Table 1: Stakeholders, and their roles as organisations and in organic cotton promotion

\begin{tabular}{|c|c|c|}
\hline $\begin{array}{l}\text { Ministry/department/ } \\
\text { institute/body }\end{array}$ & Role of the organisation & Role for organic cotton promotion \\
\hline MNFS\&R, Islamabad & $\begin{array}{l}\text { MNFS\&R (or the Ministry of Agriculture) is a cabinet-level ministerial } \\
\text { department of the Government of Pakistan responsible for implementing, } \\
\text { enforcing, developing, and executing policy on agriculture, livestock, and } \\
\text { fishing. }\end{array}$ & $\begin{array}{l}\text { Supports policy work and the engagement of } \\
\text { line departments, such as FSC\&RD and the } \\
\text { PCCC, in work on the seed domain. }\end{array}$ \\
\hline $\begin{array}{l}\text { Pakistan Central } \\
\text { Cotton Committee } \\
\text { (PCCC), Islamabad }\end{array}$ & $\begin{array}{l}\text { Under MNFS\&R, the PCCC is an independent and autonomous committee with } \\
\text { the mandate to improve and develop the growing and manufacturing of cotton } \\
\text { and cotton by-products through an extensive R\&D programme. The PCCC has } \\
\text { established a chain of research institutes across the country to conduct applied } \\
\text { research on cotton. The PCCC is responsible for a monocrop (cotton) but also } \\
\text { for multidisciplinary activities, the conduct of National Coordinated Varietal } \\
\text { Trials, legislative measures, and market and economic research on cotton. }\end{array}$ & $\begin{array}{l}\text { Supports policy work and practical } \\
\text { engagement for securing non-GMO cotton } \\
\text { seed, developing non-GMO varieties, and } \\
\text { varietal testing at different organic cotton } \\
\text { seed hubs. }\end{array}$ \\
\hline $\begin{array}{l}\text { Pakistan Agriculture } \\
\text { Research Council } \\
\text { (PARC) }\end{array}$ & $\begin{array}{l}\text { PARC is a top national organisation working in close collaboration with other } \\
\text { federal and provincial institutions to provide science-based solutions } \\
\text { for agriculture. PARC works to develop high-yielding crop varieties for all } \\
\text { ecological zones, undertake aid, promote and coordinate agricultural research, } \\
\text { arrange expeditious utilisation of research results at farm level, create research } \\
\text { establishments (mainly to fill gaps in existing agricultural research } \\
\text { programmes), arrange the training of high-level scientific manpower in } \\
\text { agricultural sciences, and generate, acquire, and disseminate information } \\
\text { relating to agriculture through its media wing at the National Agriculture } \\
\text { Research Centre, Islamabad. }\end{array}$ & $\begin{array}{l}\text { Supports policy draft preparation under the } \\
\text { Organic Agriculture Institute of PARC, } \\
\text { facilitates field support to farmers through } \\
\text { the Balochistan Agricultural Research and } \\
\text { Development Centre, and tests available } \\
\text { biofertiliser products. }\end{array}$ \\
\hline $\begin{array}{l}\text { Agriculture Policy } \\
\text { Institute (API), Islamabad }\end{array}$ & $\begin{array}{l}\text { API is an important institute responsible for analysing the impact of } \\
\text { important agricultural policies on relevant groups (such as consumers, } \\
\text { processors, and exporters) and advising MNFS\&R on policy adjustments } \\
\text { needed for greater efficiency and equity. }\end{array}$ & $\begin{array}{l}\text { Supports organic cotton policy development. } \\
\text { It can review and support policy drafts. }\end{array}$ \\
\hline FSC\&RD & $\begin{array}{l}\text { FSC\&RD is an attached department of MNFS\&R, with headquarters in } \\
\text { Islamabad and } 27 \text { field offices/laboratories throughout Pakistan. FSC\&RD has } \\
\text { the mandate to regulate the quality of seed of various crops under the legal } \\
\text { provisions of the Seed Act } 1976 \text {, the Seed (Amendment) Act } 2015 \text {, and related } \\
\text { rules and regulations. FSC\&RD also acts as the executive arm of the National } \\
\text { Seed Council of Pakistan. FSC\&RD is engaged with the following activities } \\
\text { through its regional and field offices spread across Pakistan: }\end{array}$ & $\begin{array}{l}\text { Supports organic cotton policy with a focus } \\
\text { on the seed domain and provides further } \\
\text { support in the field for seed certification. }\end{array}$ \\
\hline
\end{tabular}


Ministry/department/

institute/body

DAE, Balochistan

Agriculture Research,

Balochistan

DAE, Punjab

DAE, Sindh

National Institute for

Genomics and Advanced

Biotechnology (NIGAB)

National Institute for

Biotechnology and

Genetic

Engineering (NIBGE)
- seed certification;

- seed testing;

- crop variety registration;

- seed company registration;

- Seed Act enforcement;

- seed technology training; and

- seed import and export.

DAE Balochistan is responsible for providing extension services to farmers throughout Balochistan and implementing agriculture development projects. Agriculture extension services are provided to farmers at district, tehsil, union council, and village level.

Department of Agriculture Research, Balochistan is responsible for providing research services for crop variety development according to the existing environmental conditions of the province. Farmer education is also conducted at Department of Agriculture Research stations.

\section{DAE, Punjab is responsible for providing extension services to farmers} throughout Punjab and implementing agriculture development projects. Agriculture extension services, through field staff offices, are provided at district, tehsil, and union council level.

DAE, Sindh is responsible for providing extension services to farmers throughout Sindh and implementing agriculture development projects. Agriculture extension services, through field staff offices, are provided at district, tehsil, and union council level.

NIGAB, under the umbrella of PARC, is responsible for studying the genes of various crops. It also provides gene testing services to farmers and organisations across Pakistan.

NIBGE is one of the main biotechnology institutes of the four bioscience centres of the Pakistan Atomic Energy Commission. It provides modern biotechnology and genetic engineering services. The research programmes at NIBGE are mainly aimed at improving agriculture, health, environment, and industry and are supported by national and international financial grants.
Supports policy work at provincial and federal levels, engages with farmers in Balochistan to produce organic cotton, and provides on-the-ground support for the implementation of the organic cotton programme in Balochistan.

Supports policy work, IPM, and varietal research in Balochistan.

Supports policy work and promotion of organic cotton in Punjab province, and provision of non-GMO seed from seed companies operating in Punjab province.

Supports policy work and promotion of organic cotton in Sindh province, and provision of non-GMO seed from seed companies operating in Sindh province.

Provides facilities for GMO testing.

Provides facilities for GMO testing. 


\begin{tabular}{|c|c|c|}
\hline $\begin{array}{l}\text { Ministry/department/ } \\
\text { institute/body }\end{array}$ & Role of the organisation & Role for organic cotton promotion \\
\hline $\begin{array}{l}\text { Nuclear Institute for } \\
\text { Agriculture and Biology } \\
\text { (NIAB) }\end{array}$ & $\begin{array}{l}\text { NIAB is an agriculture and food irradiation national research institute managed } \\
\text { by the Pakistan Atomic Energy Commission. } \\
\text { NIAB has four important research divisions engaged in agriculture and biology } \\
\text { related research: } \\
\text { - plant breeding and genetics; } \\
\text { - soil and environmental sciences; } \\
\text { - plant protection; and } \\
\text { - animal science. }\end{array}$ & $\begin{array}{l}\text { Provides: } \\
\text { - support in policy drafting with a focus on } \\
\text { the seed domain; } \\
\text { - practical support in the provision of non- } \\
\text { - GMO seed; } \\
\text { - development of non-GMO varieties; } \\
\text { - fields for non-GMO seed multiplication; } \\
\text { - training to farmers on seed multiplication } \\
\text { - techniques; and } \\
\text { - quality assurance of non-GMO seed. }\end{array}$ \\
\hline $\begin{array}{l}\text { Central Cotton Research } \\
\text { Institute (CCRI), Multan }\end{array}$ & $\begin{array}{l}\text { CCRI Multan has been advancing and generating knowledge in cotton R\&D } \\
\text { since its establishment in } 1970 \text {. Over the years, many achievements have been } \\
\text { made in the development of high-yielding varieties with standard fibre quality } \\
\text { characteristics such as staple length, fineness, strength, etc. }\end{array}$ & $\begin{array}{l}\text { Supports policy drafting (with a focus on the } \\
\text { seed domain), and provides practical } \\
\text { support in the provision of non-GMO seed } \\
\text { and development of non-GMO varieties, } \\
\text { fields for non-GMO seed multiplication, and } \\
\text { training to farmers on seed multiplication } \\
\text { techniques. Also offers quality assurance of } \\
\text { non-GMO seed. }\end{array}$ \\
\hline CCRI, Sakrand & $\begin{array}{l}\text { CCRI Sakrand is a cotton research institute that serves Sindh's ecological } \\
\text { areas. The institute has advanced and generated knowledge on cotton R\&D. }\end{array}$ & $\begin{array}{l}\text { Supports policy drafting (with a focus on the } \\
\text { seed domain), and provides practical } \\
\text { support in the provision of non-GMO seed } \\
\text { and development of non-GMO varieties, } \\
\text { fields for non-GMO seed multiplication, and } \\
\text { training to farmers on seed multiplication } \\
\text { techniques. Also offers quality assurance of } \\
\text { non-GMO seed. }\end{array}$ \\
\hline $\begin{array}{l}\text { Cotton Research } \\
\text { Institute, Ayyub } \\
\text { Agriculture Research } \\
\text { Institute (AARI), Punjab }\end{array}$ & $\begin{array}{l}\text { The Cotton Research Institute (under the umbrella of AARI, Faisalabad) is } \\
\text { working to develop high-yielding cotton varieties suitable for the ecological } \\
\text { zones of Punjab. }\end{array}$ & $\begin{array}{l}\text { Supports policy drafting (with a focus on the } \\
\text { seed domain), and provides practical } \\
\text { support in the provision of non-GMO seed } \\
\text { and development of non-GMO varieties, } \\
\text { fields for non-GMO seed multiplication, and } \\
\text { training to farmers on seed multiplication } \\
\text { techniques. Also offers quality assurance of } \\
\text { non-GMO seed. }\end{array}$ \\
\hline
\end{tabular}


Ministry/department/

institute/body

PCSI, Karachi

Karachi Cotton

Association (KCA)

Pakistan Cotton Ginners

Association (PCGA)

All Pakistan Textile Mills

Association (APTMA)

Punjab Seed Corporation (PSC)

Sindh Seed Corporation

Seed companies in

Punjab and Sindh

Chamber of Agriculture,

Sindh;

Chamber of Agriculture,

Punjab;
PCSI has the mandate to perform the following key functions:

- establish and promote a cotton standardisation programme based on

internationally-accepted grading and classification systems;

- set up grades and standards for cotton seed and lint cotton; and

- train cotton graders, classers, arbitrators, and instructors.

$\mathrm{KCA}$ is the face of cotton-associated activities in Pakistan. All stages of the

value chain are represented on the Board of Directors. KCA maintains a code of fair and equitable trading practices in the form of rules, regulations, and bylaws. It maintains a suitable set of standards for the classification of cotton. It handles matters affecting the general interests of the cotton trading community. It offers buyers and sellers opportunities to obtain useful information regarding global cotton prices and market conditions.

The PCGA works towards improving cotton practices and policies. The PCGA

is well aware of the social and economic importance of cotton, not only in

Pakistan but all over the world.

APTMA is the premier national trade association of the textile spinning,

weaving, and composite mills, representing the organised sector in Pakistan. APTMA represents 396 textile mills, of which 315 are spinning, 44 are weaving and 37 are composite units.

PSC is engaged in the production of basic seed directly and indirectly through the assistance of registered growers. It also maintains a sound system for the effective distribution of quality seed. Quality seed of all major crops including cotton are provided to farmers in Punjab.

Sindh Seed Corporation is engaged in the production of basic seed, directly and indirectly through the assistance of registered growers. Quality seed of all major crops including cotton and wheat is provided to farmers in Sindh. Multiplication of the available stock of non-GMO seed.

Farmers' organisations work for the benefit of farmers through raising issues with the government and advocating for policies and packages, as well as premiums and subsidies, for farmers.
Supports policy drafting, specifically on cotton standardisation, and trains stakeholders.

Supports policy for trade-related aspects.

Support on policy and developing organic cotton ginning and promotion of organic cotton.

Supports PTP matters and other challenges faced by Pakistan's textile sector.

Support on the provision, varietal testing, and multiplication of non-GMO seed at designated farms.

Support on the provision, varietal testing, and multiplication of non-GMO seed at designated farms.

Supports the provision of non-GMO seed, and multiplication of non-GMO varieties with quality assurance.

Supports policy work to sensitise the government to promote organic cotton as a commodity, provides farm land for furthe seed multiplication, and coordinates with 
Ministry/department/

institute/body

Farmer organisations,

Balochistan

Husein Ebrahim Jamal

Research Institute,

University of Karachi
Role of the organisation

Role for organic cotton promotion

government departments for the benefit of

the farming community.

Provides seed testing facilities to ensure international standards and

International Organisation for Standardisation (ISO) certification are

maintained.
Provides GMO testing following ISO certified

standards. 


\section{Policy working groups}

The CAPAS project is creating a conducive environment in order to develop Pakistan's first organic cotton policy through the active engagement and participation of all relevant cotton stakeholders. Three provincial working groups and one federal-level working group will be formed by the end of 2021 to draft an organic cotton policy, circulate it to various provincial and federal authorities, and lobby for its approval from appropriate legislative forums. The working groups will be as follows:

- Federal organic cotton working group;

- Balochistan organic cotton working group;

- Punjab organic cotton working group; and

- Sindh organic cotton working group.

\section{Stakeholders}

The CAPAS project has identified potential stakeholders for these working groups which will work for the next 3-4 years on an organic cotton policy document (Table 2).

Table 2: Potential stakeholders for the working groups

\begin{tabular}{|l|l|}
\hline Designation & Ministry/departments/institutes/bodies \\
\hline Cotton commissioner & MNFS\&R Islamabad \\
\hline Vice president & PCCC Islamabad \\
\hline Chairman & PARC \\
\hline Director general & API Islamabad \\
\hline Director general & FSC\&RD \\
\hline Director general & DAE Balochistan \\
\hline Director general & Department of Agriculture Research Balochistan \\
\hline Director & NIBGE \\
\hline Director & CCRI Multan \\
\hline Director & Cotton Research Institute, AARI Punjab \\
\hline Joint director & PCSI Karachi \\
\hline Chairman & PCGA \\
\hline Director & APTMA \\
\hline Representatives & Farmers' organisations, Punjab, Sindh, and Balochistan \\
\hline Representatives & Parliamentarian, Balochistan \\
\hline Representatives & CABI \\
\hline Representatives & WWF-Pakistan \\
\hline Representatives & $\begin{array}{l}\text { Clothing companies: Junaid Jamshed, Alkaram, Khaadi, ChenOne, Gul } \\
\text { Ahmed, and Nishat Linen }\end{array}$ \\
\hline
\end{tabular}




\section{Key responsibilities}

- Identify, discuss, and suggest implications and gaps in organic cotton policy.

- Facilitate collaboration and build synergy among partners/stakeholders dealing with the issues of organic agriculture policy and multiplication of non-GMO cotton seed.

- Strengthen the commitment and capacity of stakeholders at all levels for a stronger voice on organic cotton in Pakistan.

- Clearly delineate the role of regulations, policies, procedures, and guidelines in the organic cotton policy.

- Appropriately designate policy briefs, procedures, and guidelines to promote organic cotton and the availability of non-GMO cotton seed in the country.

- Policy advocacy for seeking subsidies on organic inputs and non-GMO seed.

- Hold and facilitate meetings with public representatives.

- Facilitate CABI in achieving CAPAS project targets regarding policy advocacy and seed initiatives in the country.

- Prepare and review draft organic cotton policy and lobbying for its approval from legislative forums of the country at federal and provincial level.

- Coordinate organic cotton matters in the legislature and executive streams in Balochistan and with other provinces.

\section{Stakeholders' stance on organic cotton policy}

\section{MNFS\&R}

MNFS\&R acknowledged that no dedicated organic cotton policy has so far been formulated. However, it is the government's desire to have an organic agriculture policy to support organic production. MNFS\&R explained that the existing Seed Act 1976 has recently been amended which has enabled the private sector to produce and trade seed more independently. As a result, private seed companies have developed a number of organic cotton varieties and some are using biotechnology to improve the potential of cotton varieties. MNFS\&R also states that the Plant Breeders' Right Act (Government of Pakistan, 2016) has provided more freedom and legal security to technology developers and breeders, and has helped to attract investment into the seed sector.

For the production of organic cotton, however, MNFS\&R acknowledges that the availability of non-GMO cotton seed is a challenge. MNFS\&R can direct all provincial and national stakeholders to draft an organic cotton policy and after its approval from all legislative forums, it may also help in its implementation. In the absence of policy, the organic cotton seed system cannot be improved, so MNFS\&R will support the organic cotton policy with CABI through its CAPAS project.

\section{PARC and NIGAB}

PARC is the apex national organisation working in close collaboration with other federal and provincial institutions in the country to provide science-based solutions to the agriculture 
sector. PARC has scientific expertise for seed testing and certification, which it believes can be used for organic cotton in collaboration with $\mathrm{CABI}$ and other stakeholders. PARC and its institute, NIGAB, are of the view that organic cotton policy is the primary gap that needs to be filled in order to attract organic cotton stakeholders.

- About $90 \%$ of the cotton grown in Pakistan is genetically modified so it is very hard to find pure non-GMO seed. To overcome this challenge the institutions believe that there should be a specified area for seed production for organic cotton, for quality assurance.

- Lack of a marketing system for organic cotton produce from farmer to market needs special attention.

- A premium should be offered to farmers.

- The non-existence of a traceability system and local organic cotton certifying body is a major challenge for farmers who have to take full responsibility for certification. PARC and NIGAB state that the government should establish a national certification system.

- Farmers' laboratory testing charges for GMO and chemical detection, which is part of the process of organic certification, should be subsidised. The institutions stated that the government could use PARC-NIGAB GMO testing facilities and subsidise the costs to promote organic cotton.

- The government should also revive R\&D in the public sector to develop non-GMO seed varieties.

- Farmer training programmes need to be initiated, such as the Farmer Field School programme, to educate farmers on GAP.

\section{API}

API has a mandate: (i) to analyse domestic and international sectoral/commodity-specific policies; (ii) to conduct studies on emerging policy issues relating to input/output production, consumption, prices, costs, marketable surplus, demand, supply, stock, and trade; (iii) to examine/estimate the production, processing, storage, and marketing costs of agricultural commodities (crops and livestock); (iv) to analyse the impact of important agricultural policies on producers, consumers, processors, exporters, and importers; and ( $v$ ) to advise on policy adjustments needed for greater efficiency and equity. Specifically, API is engaged in price policy for cotton seed.

At present, with new leadership, API is in the process of reform with the help of international organisations such as the International Food Policy Research Institute, FAO, and CABI. API has the technical knowledge capacity to organise policy dialogues, create technical working groups for policy input, and organise stakeholder workshops to draft policies. These services can be offered to all agriculture sectors and subsectors in Pakistan's federal or provincial departments. API is already working on crop standards set by the FAO. This needs to be disseminated through farmers' workshops, which can be organised by API-CABI. API highlighted other issues that needed special attention to promote organic cotton:

- The right incentives and market information system may help farmers adopt organic agriculture, including cotton. 
- Both provincial and federal institutes and departments need to be sensitised on organic cotton seed R\&D activities.

- There is a need to educate farmers - through media sources or a farmer schooling system - about the benefits of growing certified organic cotton seed.

- A specific organic agriculture/cotton policy is required.

- High-yielding varieties and bio-inputs should be made available for organic cotton producers.

- A national organic quality assurance system should be created.

- A competitive financial incentive (organic cotton premium) is required.

\section{CCRI Multan}

CCRI Multan has been working to develop non-GMO cotton varieties since 1973. Since the inception of $\mathrm{CCRI}$ it has introduced more than 20 non-GMO cotton varieties which are suitable for different ecological zones of the country.

Regarding an organic cotton policy, CCRI Multan states that:

- Organic cotton hotspots, for its production on a large scale, which is particularly important for seed multiplication, need to be identified.

- Farmers in Sindh, Punjab and Balochistan should be registered for organic cotton production and they must be trained in organic cotton agronomic matters.

- Financial incentives for organic cotton (an organic premium) will encourage farmers to adopt organic cotton production and compensate them for the yield gaps between conventional and organic cotton.

- CCRI Multan is now producing non-GMO seed in isolated areas to avoid contamination. This basic non-GMO seed will be provided for organic cotton and seed production in organic zones.

\section{Department of Agriculture Research Balochistan}

The Department of Agriculture Research has the task of working on biological control, the development of IPM, and the control of nematodes and viruses affecting different crops, vegetables, and fruits in Balochistan.

The Department of Agriculture Research acknowledged that no initiatives have been adopted yet for organic cotton seed policy development and implementation in Balochistan. The department is interested in working with $\mathrm{CABI}$ to develop non-GMO cotton seed in Balochistan because the department is well equipped with technical and scientific expertise and is ready to collaborate on CABI's CAPAS project.

\section{DAE Balochistan}

DAE with the collaboration of WWF-Pakistan, launched a 3-year project (2016-2019) entitled 'Organic Cotton Cultivation Promotion with Small and Marginal Tribal Farmers in Balochistan' 
with the financial support of the Laudes Foundation. DAE Balochistan is working with organic cotton farmers in Barkhan and Lasbela districts of Balochistan to grow non-GMO cotton and use organic manure and compost for soil fertilisation rather than using chemical fertilisers.

DAE Balochistan admitted that Balochistan is totally dependent on other provinces, especially Punjab, for all crop seed, including non-GMO cotton seed and organic cotton foundation seed.

DAE Balochistan is of the view that:

- Strict policies are needed to ensure the availability of organic cotton seed (it was not available during 2019-2020 throughout the country), which is a threat to organic cotton promotion and production and its sustainability in Balochistan.

- There should be a cotton seed supply chain so farmers can access organic seed on time and the government should subsidise it.

- They will support the development of an organic cotton policy and regulate the Organic Cotton Act at a provincial level.

- There should be free distribution of organic cotton seed, at least for a period of 3 years, and distribution of machinery to organic cotton growers, in addition to extending financial support for organic cotton farmers and other related support policies.

- The government should focus on developing organic regions. They should issue an order for the complete banning of chemical fertilisers, pesticides, and GMO seed within potential organic cotton regions, and allocation of at least 5 acres under organic cotton depending upon the availability of cultivable land by each of the cotton progressive farmers.

- For wider promotion and engagement with policy holders, national-level and provinciallevel committees on organic cotton must be established.

- There should be investment in processing, training and marketing to promote organic agriculture.

- Balochistan is not fortunate enough to enjoy well-developed information and communication (ICT) infrastructure which is a challenge for cotton supply chain development, and attracting investment into the area. Policy level intervention should be included to sensitise the government on the importance of improving ICT infrastructure for the benefit of businesses and the cotton supply chain in Balochistan.

- Tax breaks for organic cotton farmers may be included in the way forward. 
- Due to resource constraints DAE Balochistan should be actively engaged by organisations like CABI and the Laudes Foundation to develop an ecosystem for an organic cotton production system in the province. During this time acceptable ecosystem and legislative frameworks should be developed with the support of $\mathrm{CABI}$ and other partners like WWF-Pakistan to support organic cotton policy and production.

\section{NIAB}

NIAB maintains approved non-GMO cotton varieties and produces non-GMO cotton seed on a regular basis. These varieties are used for developing basic and pre-basic seed of true-totype cotton seed for distribution to cotton growers. Currently, the cotton seed regulation process is being implemented through FSC\&RD. To promote organic cotton, NIAB proposes an organic cotton premium price in Pakistan to encourage farmers to adopt organic cotton production.

\section{AARI}

AARI is engaged in developing new cotton varieties. AARI suggests implementation of the Seed Act 1976, amended in 2015, in letter and spirit and the implementation of a seed production system, but also highlighted a number of challenges that need to be overcome for promoting an organic cotton production system in Pakistan.

- Non-GMO seed availability is the most important factor in developing an organic cotton ecosystem in Pakistan, yet the powers of seed certification are vested with FSC\&RD, which has a shortage of staff and a lack of capacity for seed testing.

- There is no competitive financial incentive (premium).

- There is an absence of an organic cotton policy.

- There is a distorted organic cotton supply chain.

- There is low demand for organic cotton by cotton ginners and manufacturers.

- There is a lack of farmers' associations in organic cotton.

\section{DAE Sindh}

DAE Sindh is engaged in crop policies, crop support, extension services, advisory services for plant protection measures, issuing working licence to the ginners, and seed marketing. The department stated that it would support the organic cotton policy at provincial and federal levels. 


\section{PCSI Karachi}

PCSI has a mandate for dealing in raw cotton quality, classification, grading, ginning, handling, standardisation, and training. The absence of strict monitoring of private seed companies by provincial and federal authorities, and the non-implementation of strict zoning of seed/variety cultivation in particular areas were both highlighted as significant problems by the institute.

To promote organic cotton production, PCSI made the following recommendations:

- Cash incentives for cotton producers would help promote organic cotton in Pakistan. Farmers and their family members would also benefit from the environmentally friendly cultivation of organic cotton.

- Multinational seed companies should be allowed by the provincial and federal governments to market their non-GMO cotton seed.

- The distribution/supply of organic seed to registered farmers should be subsidised or provided for free to promote organic cotton.

- PCSI should create guidelines to improve organic cotton quality, ginning, grading, classing, handling, and marketing.

- Joint ventures and joint projects in the field of raw cotton picking, grading, classing, ginning, handling, and standardisation should be initiated with PCSI.

- There should be gradewise segregation and ginning of organic cotton to achieve high germination rates of organic seed from higher-grade cotton seed.

- A joint supervised ginning scheme with PCSI should be initiated for the production of high-quality lint.

- Higher grade (grade 1 and grade 2) cotton seed needs to be preserved by the private and public organisations for sowing in the following season.

- Agriculture department officers and officials should be trained as organic certification and testing experts.

- There is a need to develop strong linkages between organic cotton growers, ginners, and seed companies to preserve non-GMO seed.

- Farmers should be registered for the cultivation of organic cotton and the introduction of a market-based organic cotton premium.

\section{Sindh Abadgar Board (SAB) (progressive farmers' organisation)}

SAB promotes agriculture activities through the dissemination and teaching of the latest crop technologies at grassroots level. The board reveals that general agriculture challenges - like timely availability of irrigation water, inputs including seed, lack of finance for small farmers, and crop prices - should be a top priority.

SAB observes that there is currently no benefit to organic cotton farmers due to low production levels, low market prices, an absence of a premium, and the lack of an organic cotton and agriculture policy. R\&D are also too weak, due to a lack of funds and technical support. SAB therefore made the following recommendations: 
- All stakeholders should sit together and develop ideal varieties, which must be of a short duration, be drought resistant, and mature early.

- Seed multiplication should be focused on meeting the demands of farmers.

- Funds for R\&D should be enhanced.

- Strict measures should be implemented for seed quality assurance.

- Private sector seed companies may be motivated to initiate R\&D for quality seed development of non-GMO varieties.

- The coastal belt of lower Sindh and Balochistan, as well as arid zones of Thar, are good for organic cotton production.

- FSC\&RD should be strengthened to carry out crop inspection and certification.

- Seed certification departments should train farmers to raise awareness and understanding about certification processes.

\section{Kauns Seed Corporation (KSC), Sindh}

KSC would take part and support the creation of an organic cotton policy. KSC thinks that provincial and federal stakeholders on cotton should think seriously about an organic cotton policy which would encourage the farming community, private businesses and cotton research institutes to promote organic cotton in Pakistan.

\section{Tassco Seed Corporation (TSC)}

TSC is engaged in pure cotton seed production and states that the availability of pure cotton seed is the biggest challenge to developing the sector. Government institutes should maintain the germplasm of non-Bt cotton seed and organic cotton seed. TSC would support a cotton seed policy and states that the best way to increase organic cotton production is to establish financial incentives (premiums).

\section{Findings from the GAP analysis}

All stakeholders engaged at the national, provincial, and district level recommended that the poor availability of non-GMO (non-Bt) cotton seed is the biggest challenge facing the development of organic cotton production in Pakistan. Bt and non-Bt contamination of cotton varieties are due to the absence of organic cotton zones, isolated from conventional cotton zones. Pure organic cotton seed multiplication should be given particular attention, and cotton institutes engaged in cotton R\&D should build their capacity for organic cotton seed development and production of required biological inputs for organic cotton production.

After organic cotton seed availability, preparation of a national organic cotton policy is the top priority for all relevant stakeholders. A free organic cotton certification facility and a range of financial incentives should also be established, to encourage farmers to join the organic cotton production system. Greater uptake of organic cotton would also help in winning stakeholder support on organic cotton policy dialogue and other related issues. 
Production of organic cotton per hectare is far lower than for conventional cotton, and attacks of pests/insects and diseases on organic cotton are much higher. This can be addressed by giving an organic cotton premium to farmers. At this stage there is absence of any wellestablished bio-input (biofertilisers, biopesticides, etc.) supply chain. Not only are these bioinputs often costlier than pesticides, they are also often fairly ineffective. Government R\&D institutes engaged in R\&D activities need to focus on biological inputs and making them more effective.

Without introducing virgin and isolated cotton zones in Punjab, Sindh, and Balochistan, organic cotton production systems and related bio-input supply chain development will struggle to develop. There are areas, such as the Potohar belt in Punjab, Thar in Sindh, and the vast virgin lands of Balochistan, where zoning for organic cotton is possible.

Although SBP has an agriculture credit policy for organic agriculture, the legal formalities for getting a loan from commercial banks restrict farmers.

\section{Recommendations}

- Develop an organic cotton policy with engagement of relevant stakeholders/working groups.

- Establish an organic cotton premium (as per the final price of textile-sector products at national and international markets) to encourage and promote organic cotton farming.

- Establish organic cotton seed multiplication programmes, with a focus on immediate, medium-term, and long-term approaches that also engage research institutes, seed companies, FSC\&RD, farming communities, etc.

- Provide free laboratory testing facilities for cotton seed and organic cotton samples of farmer's fields.

- Establish a national organic certification system for organic cotton textile products.

- Carry out an ethnobotanical survey to identify local plant varieties that can be used as raw materials in the preparation of biopesticides, and develop a supply chain of medicinal plants and their products for starting income generation activities.

- Establish a bio-inputs supply chain for effective control of organic cotton insect, pests and diseases.

- Create an organic cotton-specialised credit facility for organic cotton farmers that requires farmers to provide minimum amounts of formal documentation.

- Include organic cotton regions in the government's priority development programme.

- Promote organic cotton at identified hotspots in Punjab, Sindh, and Balochistan.

- Include youth, especially women, in organic agriculture and organic cotton and bioinput businesses for job creation and enterprise development in the region. 


\section{References}

Cororaton, C.B. and Orden, D. (2008) Pakistan's Cotton and Textile Economy: Intersectoral Linkages and Effects on Rural and Urban Poverty. Research Report 158. International Food Policy Research Institute (IFPRI), Washington, DC, xi + 107 pp. Available at:

http://www.ifpri.org/sites/default/files/publications/rr158.pdf (accessed 11 January 2021).

Government of Balochistan (2015) Balochistan Agriculture Sector Policy and Strategy.

Agriculture Department Balochistan, Quetta, Pakistan, 35 pp. Available at:

http://www.fao.org/faolex/results/details/en/c/LEX-FAOC173418/ (accessed 11 January 2021).

Government of Pakistan (1960) The Cotton Transport Act, 1923, amended 1960. The Government of Pakistan, Islamabad, Pakistan, [4 pp.]. Available at:

http://ilo.org/dyn/natlex/docs/ELECTRONIC/99445/118724/F937914755/PAK99445.pdf (accessed 11 January 2021).

Government of Pakistan (1976) Pakistan Seed Act, 1976. Government of Pakistan, Federal Seed Certification Department, Ministry of Food, Agriculture and Co-operatives. Available at: http://extwprlegs1.fao.org/docs/pdf/pak16066.pdf and http://na.gov.pk/uploads/documents/1438327528 958.pdf (accessed 12 January 2021).

Government of Pakistan (2002) The Cotton Standardization Ordinance, 2002. The Government of Pakistan, Islamabad, Pakistan, [8 pp.]. Available at:

http://agripunjab.gov.pk/system/files/The\%20Cotton\%20Standardization\%20Ordinance\%2C \%202002.pdf (accessed 11 January 2021).

Government of Pakistan (2005) Pakistan Biosafety Guidelines, 2005. Pakistan

Environmental Protection Agency, Ministry of Climate Change, Islamabad, Pakistan, p. 138.

Available at: http://www.environment.gov.pk/images/guidelines/BiosftyGlines2005.pdf (accessed 12 January 2021).

Government of Pakistan (2015) Pakistan Textile Policy 2014-2019. Ministry of Textile, Islamabad, Pakistan, p. 22. Available at:

http://textile.gov.pk/moti/userfiles1/file/Textile\%20Policy\%202014-19.pdf (accessed 12 January 2021).

Government of Pakistan (2016) The Plant Breeders' Rights Act. http://nasirlawsite.com/laws/pbra.htm (accessed 11 January 2021)

Government of West Pakistan (1966) The Punjab Cotton Control Ordinance, 1966. Government of West Pakistan, Islamabad, [13 pp.]. Available at:

http://extwprlegs1 fao.org/docs/pdf/pak71036.pdf (accessed 11 January 2021).

Pakistan Central Cotton Committee (2020) Cotistics: Annual Cotton Statistical Bulletin http://www.pccc.gov.pk/pdf\%20files/Cotistics\%20Book\%202020.pdf (accessed 11 January 2021) 


\section{contact CABI}

\section{Africa}

Kenya

CABI, Canary Bird

673 Limuru Road, Muthaiga

PO Box 633-00621

Nairobi, Kenya

T: +254 (0)20 2271000/ 20

E: africa@cabi.org

\section{Ghana}

CABI, CSIR Campus

No. 6 Agostino Neto Road

Airport Residential Area

P. O. Box CT 8630, Cantonments

Accra, Ghana

T: +233 (0)302 797202

E: westafrica@cabi.org

Zambia

CABI, Southern Africa Centre

5834 Mwange Close

Kalundu

P.O. Box 37589

Lusaka, Zambia

T: +260967619665

E: westafrica@cabi.org

\section{Americas}

Brazil

CABI, UNESP-Fazenda Experimental Lageado, FEPAF (Escritorio da CABI)

Rua Dr. Jose Barbosa de Barros 1780

Fazenda Experimental Lageado

CEP:18.610-307

Botucatu, São Paulo, Brazil

T: + 5514-38826300

E: y.colmenarez@cabi.org

Trinidad \& Tobago

CABI, Gordon Street, Curepe

Trinidad and Tobago

T: +18686457628

E: caribbeanLA@cabi.org

USA

CABI, 745 Atlantic Avenue

8th Floor, Boston,

MA 02111, USA

T: +1 (617) 682-9015

E: cabi-nao@cabi.org

\section{Asia}

China

CABI, Beijing Representative Office

Internal Post Box 85

Chinese Academy of Agricultural Sciences

12 Zhongguancun Nandajie

Beijing 100081, China

T: +86 (0)10 82105692

E: china@cabi.org

\section{India}

CABI, 2nd Floor, CG Block,

NASC Complex, DP Shastri Marg

Opp. Todapur Village, PUSA

New Delhi - 110012, India

T: +91 (0)1125841906

E: cabi-india@cabi.org

Malaysia

CABI, PO Box 210,

43400 UPM Serdang

Selangor, Malaysia

T: +60 (0)3 89432921

E: cabisea@cabi.org

Pakistan

CABI, Opposite 1-A,

Data Gunj Baksh Road

Satellite Town, PO Box 8

Rawalpindi, Pakistan

T: +92 (0)519290132

E: sasia@cabi.org

\section{Europe}

Switzerland

CABI, Rue des Grillons 1

$\mathrm{CH}-2800$ Delémont, Switzerland

T: + 41 (0)32 4214870

E: europe-CH@cabi.org

UK

CABI, Nosworthy Way

Wallingford, Oxfordshire, OX10 8DE, UK T: +44 (0)1491832111

E: corporate@cabi.org

CABI, Bakeham Lane

Egham, Surrey, TW20 9TY, UK

T: + 44 (0)1491 829080

E: cabieurope-uk@cabi.org

E:microbialservices@cabi.org 